\title{
Assessment of soil erosion vulnerability in the heavily populated and ecologically fragile communities in Motozintla de Mendoza, Chiapas, Mexico
}

\author{
Selene B. González-Morales ${ }^{1}$, Alex Mayer $^{2}$, and Neptalí Ramírez-Marcial ${ }^{3}$ \\ ${ }^{1}$ Facultad de Ingeniería, Universidad de Ciencias y Artes de Chiapas, Tuxtla Gutiérrez, Chiapas, Mexico \\ ${ }^{2}$ Department of Civil and Environmental Engineering, Michigan Technological University, Houghton, Michigan, USA \\ ${ }^{3}$ Departamento de Conservación de la Biodiversidad, El Colegio de la Frontera Sur, \\ San Cristóbal de las Casas, Chiapas, Mexico
}

Correspondence: Alex Mayer (asmayer@mtu.edu)

Received: 7 August 2017 - Discussion started: 1 November 2017

Revised: 5 March 2018 - Accepted: 28 May 2018 - Published: 13 June 2018

\begin{abstract}
Variability in physical rates and local knowledge of soil erosion was assessed across six rural communities in the Sierra Madre del Sur, Chiapas, Mexico. The average erosion rate estimated using the RUSLE model is $274 \mathrm{tha}^{-1} \mathrm{yr}^{-1}$, with the estimated erosion rates ranging from 28 to $717 \mathrm{tha}^{-1} \mathrm{yr}^{-1}$. These very high erosion rates are associated with high rainfall erosivity (17000 $\mathrm{MJ} \mathrm{mm} \mathrm{ha}^{-1} \mathrm{~h}^{-1} \mathrm{yr}^{-1}$ ) and steep slopes (mean slope $=67 \%$ ). Many of the highest soil erosion rates are found in communities that are dominated by forestland, but where most of the tree cover has been removed. Conversely, lower erosion rates are often found where corn is cultivated for most of the year. According to the results of the soil erosion KAP (knowledge, attitude and practices) survey, awareness of the concept of soil erosion was reasonably high in all of the communities, but awareness of the causes of erosion was considerably lower. More than half of respondents believed that reforestation is a viable option for reducing soil erosion, but only a third of respondents were currently implementing reforestation practices. Another third of the respondents indicated that they were not following any soil conservation practices. Respondents indicated that adoption of government reforestation efforts have been hindered by the need to clear their land to sell forest products or cultivate corn. Respondents also mentioned the difficulties involved with obtaining favorable tree stocks for reforestation. The KAP results were used to assess the overall level of motivation to solve soil erosion problems by compiling negative responses. The relationship between the magnitude of the soil
\end{abstract}

erosion problem and the capacity to reduce soil erosion is inconsistent across the communities. One community, Barrio Vicente Guerrero, had the highest average negative response rate and the second highest soil erosion rate, indicating that this community is particularly vulnerable.

\section{Introduction}

Soils contribute critical ecosystem services to humans, including, but not limited to food, clean water and air, and biodiversity (Pimentel and Burges, 2013; Brevik et al., 2015; Smith et al., 2015; Baveye et al., 2016). However, global estimates indicate that the fraction of land with highly degraded soils had increased from $15 \%$ of total land area in 1991 to $25 \%$ by 2011 ; most of this degradation is associated with water-induced soil erosion (UNCCD, 2013). The sustainability of soil-based ecosystem services depends on management choices by individuals, such as landowners, and institutions that set policies directly and indirectly impacting soil resources (Knowler and Bradshaw, 2007; Gomiero, 2016; Keesstra et al., 2016a; Altieri, 2018). Soil erosion challenges tend to be greatest in the more heavily populated, underdeveloped, and ecologically fragile areas, where the adaptive capacity is weakest (Leh et al., 2013; Erkossa et al., 2015). In many instances, soil erosion and other land degradation processes result from social marginalization and limited economic and technological resources. This, in turn, re- 
sults in landowner practices that favor economic gain over soil conservation (Pielke et al., 2007; Santibañez and Santibáñez, 2007; Tesfahunegn, 2013).

Human activities that contribute to soil degradation include urbanization, road construction, deforestation, intensive livestock grazing, and agriculture (Brooks et al., 2003). In Mexico, $45 \%$ of the land area is severely or very severely degraded by water-induced erosion, aggravated by conversion from forested to agricultural land and the accompanying cultivation practices (SEMARNAT, 2008). The underlying drivers of land conversion in Mexico are complex and vary among regions (Blackman et al., 2015). The state of Chiapas has experienced some of the highest deforestation and soil erosion rates in Mexico (De Jong et al., 1999; Cayuela et al., 2006), particularly in areas such as in the Grijalva River basin (Laino-Guanes et al., 2016). Soil erosion in the basin threatens the sustainability of local subsistence agriculture, puts downstream communities at risk of geologic hazards (such as landslides), and jeopardizes the downstream hydropower generation capacity (Laino-Guanes et al., 2016). The Grijalva River basin is located primarily in southern Mexico, although the headwaters are in Guatemala (González-Espinosa and Brunel-Manse, 2014). The basin has an annual average precipitation of between 1200 and $4000 \mathrm{~mm}$ and is prone to flooding and erosion due to steep slopes and fragile soils (Gutierrez-Horacio and Triana-Ramirez, 2006). Soils in the Grijalva River basin are degraded over more than half the basin area due to erosion (Ramírez-Marcial et al., 2001), with negative impacts on rural social development (GarcíaBarrios et al., 2009). Erosion is also problematic because the collection of sediment in reservoirs threatens the production of hydropower in the basin, which provides $42 \%$ of the total hydropower in Mexico (CFE, 2013). Motozintla de Mendoza, a municipality located in the upper portion of the Grijalva River basin and the subject of this study, has experienced severe erosion from catastrophic events such as Hurricane Mitch (1998) and Hurricane Stan (2005) (SánchezNuñez et al., 2012); these two natural hazards caused sediment at least three meters in depth to accumulate in areas adjacent to hillslopes and long-term erosion hazards (SuarezDiaz, 2006; Sánchez-Nuñez et al., 2012).

While land degradation is often assumed to be a deliberate result of human intervention, in certain socio-environmental contexts, degradation is not perceived as deliberate by local actors; instead their actions come as a result of learning and adapting to new conditions, such as climate change (Gomiero, 2016; Wilson et al., 2016; Altieri, 2018). Successful long-term soil conservation and restoration programs need to simultaneously identify areas that are most vulnerable to erosion and consider the needs and interests of the people who could be directly or indirectly impacted (ToledoAceves et al., 2011; Assefa and Bork, 2015). Thus, the assessment and resolution of soil erosion problems requires not only physical analyses and technical intervention but also an understanding of the underlying social factors (Pereira et al.,
2016; González-Espinosa et al., 2015; Blaikie and Brookfield, 2015; Keesstra et al., 2016b). Since landowner perceptions are generally dependent on the cultural and sociopolitical context of a given area, it is necessary to carry out studies that integrate local perceptions, preferences, and attitudes regarding soil management (Subirós et al., 2016).

However, most studies underlying soil conservation and restoration programs do not ask those affected by soil erosion for their input on the causes and potential solutions (Kelly et al., 2009; Marques et al., 2015). This lack of interaction with the group of people most familiar with the issues surrounding soil erosion may explain why the problem persists, despite a long history of research and programs aimed at encouraging farmers to adopt soil conservation practices (Zegeye et al., 2010; Jara-Rojas et al., 2013; Teshome et al., 2014). The decision of landowners to use and manage the land in a way that minimizes erosion depends on their perception of the landscape (Marques et al., 2015). If the farmers perceive the problems related to soil erosion and understand their responsibility regarding managing their own land, they may be willing to adopt new, soil-conserving practices (Assefa and Bork, 2015). An understanding of landowners' knowledge and attitudes can result in more efficient implementation of soil conservation policy measures, underscoring the need to use information about social perceptions and cultural values in management and planning (Marques et al., 2015).

Previous research in the Motozintla de Mendoza region, in Chiapas, has revealed that environmental problems are often linked to the fragmented governance of natural resources, which leads to a decline in the local inhabitant's environmental concern and connection to the local landscape (OchoaGaona, 2001; Ochoa-Gaona and González-Espinosa, 2000; Cayuela et al., 2006; Laino-Guanes et al., 2016). This finding suggests that engaging local communities in soil conservation efforts is not a straightforward issue in the region. Furthermore, the assessment of the relationship between people and environmental issues, including their perceptions of the importance of environmental issues and their willingness to participate in practices that minimize environmental impacts, is needed. Knowledge, attitudes, and practices (KAP) surveys are often used to collect information on a specific population regarding what is known, what they believe, and what they do or have been doing, primarily in relation to public health issues (WHO, 2008; Launiala, 2009). KAP surveys are straightforward to design and interpret and have been used in a broad range of environmental and natural resources management applications (e.g., Gumucio, 2011; Sibiya and Gumbo, 2013; Tuyet-Hanh et al., 2013; Babbar et al., 2014; Aparicio-Effen et al., 2016). When applied to soil erosion and management, knowledge includes causes and locations of erosion in the community, attitudes include the perceptions of the magnitude of the problem and who is responsible for the problem, and practices include the level of adoption of soil conservation methods (e.g., Ajayi, 2007). 
Natural resource managers need to understand the spatial variations in vulnerability to soil erosion, so that they can identify "hot spots" where soil degradation is especially intensive and prioritize the implementation of soil conservation and restoration efforts (Biswas et al., 2015). However, most studies of spatial variations in soil erosion vulnerability focus only on the physical aspects and not the socioeconomic dimensions that relate to the potential for soil conservation efforts to be sustainable. Therefore, we propose that spatial variation in vulnerability to soil erosion should incorporate both a biophysical metric of the risk of soil erosion and a measure of community members' views of the problem. The goal of this paper is to assess soil erosion rates and understand the relationship between knowledge, attitudes, and practices to mitigate soil erosion in six communities in the municipality of Motozintla de Mendoza, Chiapas - an area that experiences severe flooding and soil erosion hazards (Sanchez-Nuñez et al., 2015). We determine the physical and social vulnerability to soil erosion in this area using the semi-empirical, process-based Revised Universal Soil Loss Equation (RUSLE) model (Renard et al., 1997) to estimate spatially variable soil erosion rates and a KAP survey to understand differences in understanding among the communities regarding soil erosion. We integrate this information to suggest ways to prioritize the communities in which soil conservation and restoration efforts may be most likely to be sustainable.

\section{Methods}

\subsection{Study area}

The research was located in six communities: Benito Juarez Centro, Carrizal Centro, Barrio Vicente Guerrero, Barrio La Union, Barrio Plan Grande in the municipalities of Motozintla de Mendoza, and Mazapa de Madero, which are all situated to the southeast of the Sierra Madre of Chiapas (see Fig. 1). The communities were chosen because of previous connections made with local community leaders through nearby academic institutions. The regional annual average daily temperature highs and lows are 24 and $14^{\circ} \mathrm{C}$, respectively. Annual precipitation ranges from 900 to $1500 \mathrm{~mm} \mathrm{yr}^{-1}$ (Gordillo, 2009). The major economic activity in these communities is subsistence agriculture, consisting mainly of cultivating corn and beans, raising cattle, and gathering firewood. The region is typified by steep slopes (average of approximately 50\% to higher than 100\%) and, combined with the overexploitation of forests, has resulted in severe soil erosion (González-Espinosa et al., 2015). The majority of the soils in study region are regosols $(51 \%$ of the study region area) and lithosols (40\% of the area) (INEGI, 2015) which are indicative of rapidly eroding lands in very steep, mountainous areas (IUSS Working Group WRB, 2015). The remainder of the soils are classified as phaeozems
(9\% of the area, INEGI, 2015), which are typical of mountain valleys. Erosion rates were estimated and associated field measurements were taken at eight plots per community with land uses or land covers (LULCs) that are typical of the individual communities; typical LULCs were determined in an intensive LULC survey in each community.

\subsection{Field measurements}

Soil sample collection took place in the six communities during summer 2011. In each community, eight $1000 \mathrm{~m}^{2}$ circular plots (Ramírez-Marcial et al., 2014) were established. Slope inclination was measured in each plot using a clinometer (McCool et al., 1997). Six soil samples were also taken in each plot at three randomly located points along a straight line at depths of 0-20 and $21-40 \mathrm{~cm}$ respectively. The soil sampling yielded a total of 288 soil samples $(6$ communities, 8 plots per community and 6 samples each plot). The soil samples were dried, sieved, and analyzed for texture using the Bouyoucos procedure (method from AS-09, NOM-021-RECNAT-2000) and organic matter using the method from Walkley and Black (AS-07, NOM021-RECNAT-2000)(SEMARNAT, 2002). The calculation of slope lengths was carried out with Google Earth, using a polygon covering the study area. In Google Earth, lines were drawn from the plot location to the end of the hillslope or to where the hillslope curvature changed from convex to concave (according to McCool et al., 1989) using the "Add Paths" and "Show Elevation Profile" tools.

\subsection{Soil erosion rate calculations with the RUSLE model}

Observations of soil erosion rates are made from experimental plots and river sediment yields (Pimentel et al., 1995; Stallard, 1998; Hooke, 2000; Lal, 2003; Wilkinson and McElroy, 2007). However, collecting these observations can be expensive. Thus, observations of soil erosion rates are usually sparse, especially in marginalized regions. An alternative approach to estimating soil erosion rates is the use of soil erosion models (Naipal et al., 2015). One of the most frequently applied models to estimate soil erosion is the semiempirical, process-based Revised Universal Soil Loss Equation (RUSLE) model (Renard et al., 1997). RUSLE uses rainfall data, soil type, topography, vegetation cover, and conservation practices to estimate soil erosion (Fernandez et al., 2003). Studies have shown that the application of the RUSLE model is a useful and efficient tool for assessing and mapping the vulnerability of soil erosion across a wide range of ecosystem types, including mountainous tropical watersheds (e.g., Millward and Mersey, 1999; Jain et al., 2001; Lu et al., 2004; Jasrotia and Singh, 2006; Dabral et al., 2008; Yue-Qing et al., 2008; Kouli et al., 2009; Pandey et al., 2009; Prasannakumar et al., 2012). However, the RUSLE model has limited reliability for large areas (Chen et al., 2011; Prasannaku- 


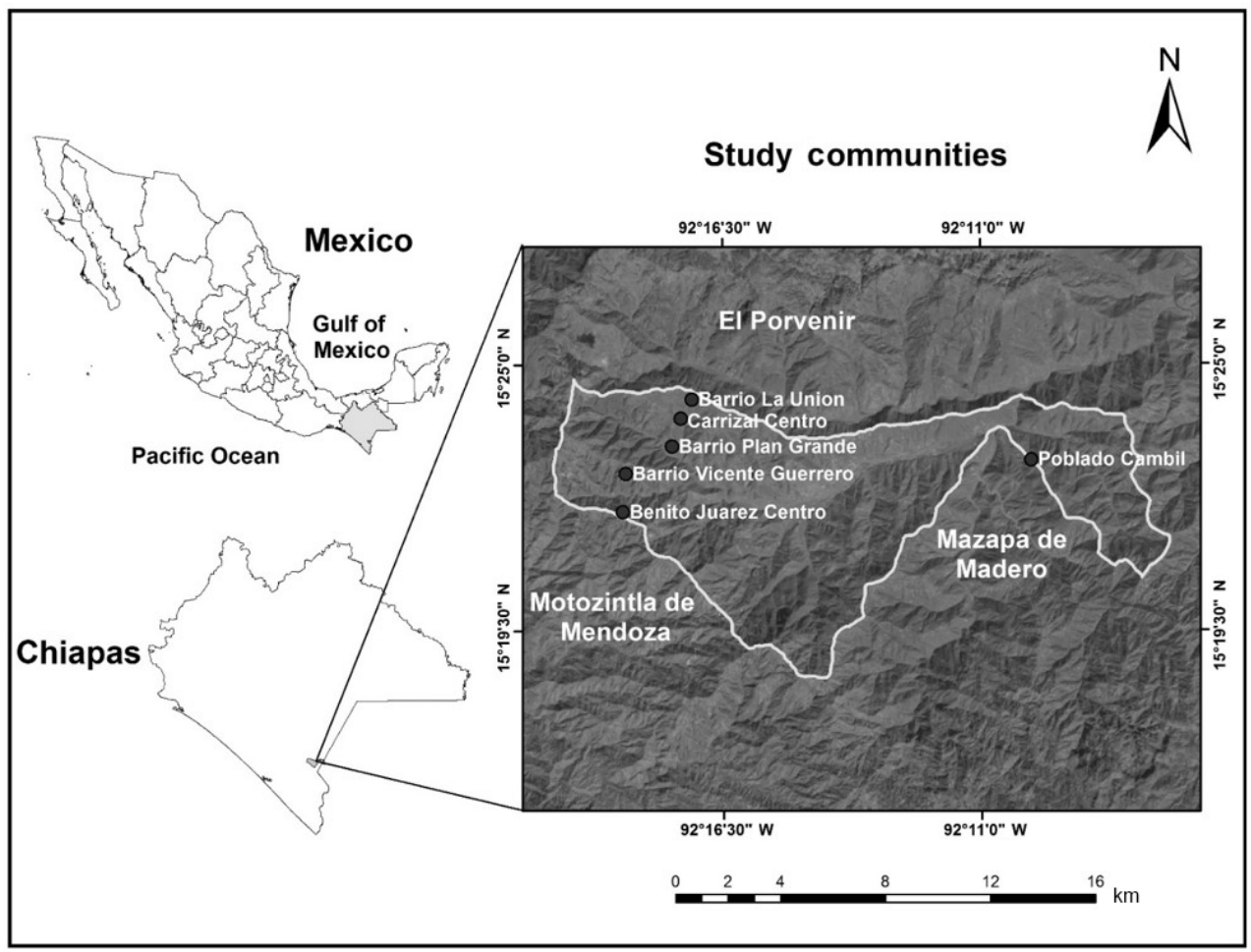

Figure 1. Study area: the Motozintla de Mendoza municipality (inside the white line) and the locations of the six study communities.

mar et al., 2011) and tends to overestimate erosion rates (Fernández and Vega, 2016; Ostovari et al., 2017).

Soil erosion rates in the RUSLE model were calculated according to Renard et al. (1997):

$A=R K L S C P$,

where $A$ is the average soil loss $\left(\mathrm{tha}^{-1} \mathrm{yr}^{-1}\right), R$ is the rainfall erosivity ( $\left.\mathrm{MJ} \mathrm{mm} \mathrm{ha}{ }^{-1} \mathrm{~h}^{-1} \mathrm{yr}^{-1}\right), K$ is the susceptibility of soils to erosion (thah ha ${ }^{-1} \mathrm{MJ}^{-1} \mathrm{~mm}^{-1}$ ), $L$ is the slope length (dimensionless), $S$ is the slope magnitude (dimensionless), $C$ is the cover and crop management factor (dimensionless), and $P$ is the conservation practice factor (dimensionless). A modified form of the conventional equation for rainfall erosivity factor was used because of the lack of highresolution rainfall data in the study area (Arnoldus, 1980; Renard and Freimund, 1994):

$R=95.77-6.081 F+0.4770 F^{2}$.

In the abovementioned equation $F$ is the modified Fournier index, as in

$F=\sum_{i=1}^{12}\left(\frac{r_{i}^{2}}{R}\right)$

In Equation 3, $r_{i}$ is the monthly precipitation and $R$ is average annual precipitation. Daily data from the period from
1980 to 2009 were obtained for the closest meteorological station (Buenos Aires, Chiapas, $7.6 \mathrm{~km}$ on average from the study communities, period of record 1998-2012) from the Comisión Nacional del Agua. The soil erodibility factor (Wischmeier et al., 1971) is a function of the physicochemical soil properties:

$$
\begin{aligned}
K= & \left(\frac{1}{7.59}\right)\left[2.1 \times 10^{-4}(12-\mathrm{OM}) M^{1.14}+3.25(s-2)\right. \\
& +2.5(p-3)] / 100
\end{aligned}
$$

where $\mathrm{OM}$ is organic matter; $M$ is the product of the modified silt size $(0.002-1.0 \mathrm{~mm})$ fractions silt size, and sand size fractions; $s$ is the structure code; $p$ is the permeability code; and 7.59 is a factor accounting for conversion from English to metric units. For more details on these variables, see RUSLE documentation (Foster, 2005). Soil textures and organic matter were measured from soil samples (see following section).

McCool et al. (1989) evaluated the slope steepness factor as

$$
\begin{aligned}
& S=10.8 \sin \theta+0.03 \text { for } \theta<9 \% \\
& S=16.8 \sin \theta-0.50 \text { for } \theta \geq 9 \%,
\end{aligned}
$$

where $\theta$ is the slope. The slope length factor was estimated using the following equation (McCool et al., 1997): 
$L=\left(\frac{\lambda}{72.6}\right)^{m}$,

where $\lambda$ is the horizontal projected length; 72.6 is the RUSLE unit plot length in feet; and $m$ is a slope exponent variable, which is related to $\beta$ as $m=\beta /(1+\beta)$ (Foster et al. (1977). For conditions where the soil is susceptible to rill and interrill erosion, McCool et al. (1989) relates $\beta$ to the local slope:

$\beta=(\sin \theta / 0.0896) /[3.0(\sin \theta) 0.8+0.56]$

The cover management factor is (Yoder et al., 1997)

$C=(\mathrm{PLU})(\mathrm{CC})(\mathrm{SC})(\mathrm{SR})(\mathrm{SM})$,

where PLU is the prior land use sub-factor (dimensionless), $\mathrm{CC}$ is the canopy cover sub-factor (dimensionless), SC is the surface cover sub-factor (dimensionless), SR is the surface roughness sub-factor (dimensionless), and SM is the soil moisture sub-factor (dimensionless). PLU is computed by

$\mathrm{PLU}=C_{f} C_{b} \exp \left[\left(-c_{\mathrm{ur}} B_{\mathrm{ur}}\right)+\left(c_{\mathrm{us}} \frac{B_{\mathrm{us}}}{C_{f} c_{\mathrm{uf}}}\right)\right]$,

where $C_{f}$ (dimensionless), $\quad C_{b}$ (dimensionless), $\quad c_{\mathrm{ur}}$ (ha mm kg${ }^{-1}$ ), and $c_{\mathrm{uf}}$, (hamm $\mathrm{kg}^{-1}$ ) are coefficients related to subsurface consolidation and soil residual organic matter; $B_{\text {ur }}$ is the mass density of live and dead roots in the upper inch of soil $\left(\mathrm{kg} \mathrm{ha}^{-1} \mathrm{~mm}^{-1}\right)$, and $B_{\mathrm{us}}$ is the mass density of incorporated surface residue in the upper inch of soil $\left(\mathrm{kg} \mathrm{ha}^{-1} \mathrm{~mm}^{-1}\right)$. CC is the canopy cover sub-factor (dimensionless) given by

$\mathrm{CC}=1-f_{\mathrm{c}} \exp (-0.1 H)$,

where $f_{\mathrm{c}}$ is the fraction of land surface covered by canopy and $H$ is the vertical distance from the land surface to the canopy (m) (Renard et al., 1997).

The surface cover sub-factor SC is given by

$\mathrm{SC}=\exp \left[-b S_{p}\left(\frac{0.24}{R_{u}}\right)^{0.08}\right]$,

where $b$ is an empirical coefficient, $S_{p}$ is the fraction of land covered by surface cover, and $R_{u}$ is the surface roughness as defined by Renard et al. (1997). The surface roughness subfactor is given by

$\mathrm{SR}=\exp \left[-0.66\left(R_{u}-0.24\right)\right]$

The soil moisture sub-factor SM is the yearly average of daily values assigned as zero and one during wet and dry periods, where wet and dry periods are determined from meteorological records. Finally, the value of the $P$ sub-factor was set equal to one, since no practices are applied for soil erosion control (Kouli et al., 2009) in the studied communities.

\subsection{KAP survey}

Prior to conducting the survey, interviews with six community members and representatives from the municipal authorities, a state government agency, and academia were conducted to understand the existing knowledge of the community with respect to soil erosion. The resulting survey was piloted with 12 community members and the survey questions were adjusted based on these results. The KAP survey of residents in the communities was carried out during the spring of 2012. Households were randomly selected, with the goal of interviewing $60 \%$ of the 396 households in the six communities, as $60 \%$ is the typical household occupancy rate in the communities. The surveys were designed for any members of a household above the age of 18 . The survey questionnaire included four sections: (1) interviewee demographic data (9 questions); (2) questions assessing existing knowledge of soil erosion (10 questions); (3) questions assessing attitudes towards soil erosion (4 questions); and (4) an openended question corresponding to the interviewee's soil erosion prevention practices. The knowledge section of the survey was aimed at determining the interviewee's understanding of what soil erosion is, their perspective on the causes of erosion, and how the land under study can be conserved either through preventive or control measures. The surveys were carried out in the Spanish language by a team of five interviewers, including the first author and four undergraduate students trained by the first author. The data collection technique was face to face interviews using the structured KAP survey methodology (Gumucio, 2011). Interviewers first explained the objective of the survey, asked for the consent of the interviewee, and then asked the survey questions as written. If further explanations were needed, they were provided in a non-technical way. The complete survey can be found in the Supplement.

\section{Results and discussion}

\subsection{RUSLE factors and soil erosion rates}

Averages and standard deviations of the variables in the RUSLE soil erosion rate Eq. (1) are shown in Table 2, averaged over each community, except for the rainfall erosivity. The rainfall erosivity factor for the study area $(R)$, based on a single climate station, was calculated as $17000 \mathrm{MJ} \mathrm{mm} \mathrm{ha}^{-1} \mathrm{~h}^{-1} \mathrm{yr}^{-1}$. This value of the $R$ factor is high, relative to values from regions such as the US and Europe, but is near the range $(R=11000$ to $14000 \mathrm{MJ} \mathrm{mm} \mathrm{ha}^{-1} \mathrm{~h}^{-1} \mathrm{yr}^{-1}$ ) reported for the state of Chiapas by Baumann et al. (2002). The high rainfall erosivity factor is primarily due to the squaring of high monthly precipitation from June to September (the average rainfall is $225 \mathrm{~mm} \mathrm{month}^{-1}$ ) (Eq. 2). However, values of $R$ estimated with correlations based on monthly precipitation, such as 
Eqs. (2) and (3), have been shown to generate higher values of $R$, compared to estimates based on higher frequency precipitation data (Yin et al., 2015).

The soil textural analysis results are as follows (mean \pm standard deviation): the organic matter fraction is $5 \pm 2 \%$, the sand fraction is $41 \pm 11 \%$, the clay fraction is $20 \pm 7 \%$, and the silt fraction is $40 \pm 8 \%$, across all plots and communities. Most $(95 \%)$ of the plot soil sample textures classify as loams $(48 \%)$, sandy loams $(21 \%)$, clay loams $(13 \%)$, and silt loams $(13 \%)$. Overall, the soil erodibility factor, $K$, ranged from 0.09 to $0.325 \mathrm{thahha}^{-1} \mathrm{MJ}^{-1} \mathrm{~mm}^{-1}$ across all of the plots and communities. The average values of $K$ obtained for each community are shown in Table 2, indicating that most of the $K$ values are between 0.018 and 0.031 tha haha ${ }^{-1} \mathrm{MJ}^{-1} \mathrm{~mm}^{-1}$. Plot samples with extremely low values of $K\left(<0.015 \mathrm{thah} \mathrm{ha}^{-1} \mathrm{MJ}^{-1} \mathrm{~mm}^{-1}, 5 \%\right.$ of the plots) tend to have higher organic matter contents and lower silt fractions; the reverse is found for the extremely high values of $K$ (>0.035 tha h ha ${ }^{-1} \mathrm{MJ}^{-1} \mathrm{~mm}^{-1}, 5 \%$ of the plots). In general, the values of $K$ estimated for the study area are relatively low, compared to, for example, a range of values found in China and the US (Zhang et al., 2008; mean of $0.038 \mathrm{thah} \mathrm{ha}^{-1} \mathrm{MJ}^{-1} \mathrm{~mm}^{-1}$ ). The values of $K$ and all other RUSLE model factors for each community and sample plot are found in the Supplement.

The LS factors, which range from 14 to 37 for the community averages, are high compared to typical values in Renard et al. (1997). These high values occur because many of the slopes on the plots were very high (mean \pm standard deviation across all plots $(\%)=67 \pm 20)$. The projected horizontal slope lengths were also high, ranging from 23 to $286 \mathrm{~m}$, indicating that long hillslopes with convex slopes are typical of the project study area.

The LULC fractions for the plots are community forestland ( $71 \%$ of plots), cultivated land (17\% of plots), pastureland ( $6 \%$ of plots), and reforested land ( $6 \%$ of plots). The computed $C$ factors range from 0.01 to 0.03 . These values are relatively low compared to, for example, lands that are completely cultivated with grain crops $(0.15$ to 0.4 ; Panagos et al., 2015), and are typical of lands with mixtures of crops and forests (Panagos et al., 2015). All plots, except the cultivated land, had substantial areas of bare soil, ranging from 60 to $95 \%$. The medium and highest $C$ factor values $(0.02-0.03)$ are found for community forestland, which is typically degraded (average bare soil coverage of $60 \%$ ) because of overexploitation for firewood collection by residents. The lowest $C$ factor values (0.01) are associated with cultivated land areas that are completely occupied by corn. In this region, corn is grown continuously with slash and burn occurring after harvest. Higher $C$ factor values are found in Barrio La Union, Ejido Carrizal, and Poblado Cambil, and are attributed to larger areas of bare soil in forested areas.

Table 2 shows the average and standard deviation values of the calculated soil erosion rates obtained for each commu- nity, along with averages and standard deviations across all plots and communities. The highest erosion rates are found in Poblado Cambil, due to relatively high soil erodibility and slope length factors in addition to the presence of especially degraded forests (average fraction of bare soil $=81 \%$ ), as indicated by the values of the cover factor for this community. Carrizal Centro, Barrio La Union, and Barrio Plan Grande had lower soil erosion rates, primarily due to lower slopes. The plots with the lowest estimated soil erosion rates also tended to have lower slopes, but also exhibited higher cover factors. The higher cover factors in these plots are usually associated with having more corn cultivation than community forest. In a study in a nearby region in Chiapas with similar land cover, high slopes, and no conservation practices, measured soil erosion rates were similar to those calculated here; however erosion rates as high as $20000 \mathrm{tha}^{-1} \mathrm{yr}^{-1}$ were found where landslides frequently recurred (Santacruz-DeLeon, 2011). For perspective on the magnitude of these soil erosion rates, the Mexican federal government describes rates greater than $200 \mathrm{tha}^{-1} \mathrm{yr}^{-1}$ as "very high" (SEMARNAT, 2008), while the Food and Agriculture Organization describes "very high" rates as exceeding $30 \mathrm{tha}^{-1} \mathrm{yr}^{-1}$ (FAO, 2015). All but one of the estimated, community-wide soil erosion rates exceed the SEMARNAT "very high" levels. For individual plots, all but one plot erosion rate exceeded the FAO "very high" level and $60 \%$ of the plot erosion rates exceed the SEMARNAT "very high" level.

\subsection{KAP surveys}

The interviews were conducted over a 15-day period and involved a total of 236 households. In total, $60 \%$ of all households in the communities were interviewed, with a range of 58 to $71 \%$ of households interviewed across the six communities. There were five non-responses, giving a non-response rate of $2 \%$. Table 1 shows the demographic details of the survey respondents. Only $14 \%$ of interviewees had an education beyond elementary school. A small fraction $(6 \%)$ had occupations other than farming their own land or as housewives (Table 1). Almost all (99\%) interviewees' had incomes that were less than or equal to MXN 1000 month $^{-1}$ (USD 56 month $^{-1}$ using the exchange rate as of 10 April 2016); of those who had incomes, $60 \%$ received government support (Table 1). The complete results of the KAP survey are provided in the Supplement.

The response to the question "Do you know what soil erosion is?" on the survey indicated that $69 \%$ of respondents did not know the term soil erosion. However, the following question, "Do you know what the most eroded area of the community is?", was accompanied by a brief explanation of soil erosion. In response, $91 \%$ of females and $95 \%$ of males were able to identify the area with most erosion. The majority of respondents $(70 \%)$ indicated that the major cause of soil erosion in their communities was either hurricanes or rainfall. Only $14 \%$ of respondents identified human 
Table 1. Demographic information for all respondents.

\begin{tabular}{|c|c|c|}
\hline Gender & Count & Percentage \\
\hline Female & 123 & $52 \%$ \\
\hline Male & 113 & $48 \%$ \\
\hline Ages (18-89) & Count & Percentage \\
\hline $18-30$ & 57 & $24 \%$ \\
\hline $31-40$ & 58 & $25 \%$ \\
\hline $41-55$ & 66 & $28 \%$ \\
\hline over 56 & 55 & $23 \%$ \\
\hline Education level & Count & Percentage \\
\hline No school & 9 & $4 \%$ \\
\hline Some elementary school & 115 & $49 \%$ \\
\hline Finished elementary school & 80 & $34 \%$ \\
\hline Some middle and high school & 30 & $13 \%$ \\
\hline Finished middle and high school & 2 & $1 \%$ \\
\hline Employment & Count & Percentage \\
\hline City (various) & 6 & $3 \%$ \\
\hline Clerical & 1 & $<1 \%$ \\
\hline Housewife & 115 & $49 \%$ \\
\hline Community (various) & 5 & $2 \%$ \\
\hline Farming & 108 & $46 \%$ \\
\hline Student & 1 & $<1 \%$ \\
\hline $\begin{array}{l}\text { Income (monthly average, } \\
\text { Mexican pesos) }\end{array}$ & Count & Percentages \\
\hline Equal to or less than 2500 & 2 & $1 \%$ \\
\hline Equal to 1500 & 2 & $1 \%$ \\
\hline Equal to or less than 1000 & 143 & $61 \%$ \\
\hline No income & 89 & $38 \%$ \\
\hline Type of income & Count & Percentage \\
\hline Government support & 142 & $60 \%$ \\
\hline No salary & 89 & $38 \%$ \\
\hline Other & 5 & $2 \%$ \\
\hline
\end{tabular}

activities - deforestation, road construction, or agriculture as causes of erosion. Conversely, most respondents $(69 \%)$ thought land use in eroded areas was associated with human activities (common forestland, cropland, grazing land, human settlements, or logging lands).

The most frequent response to the question regarding the consequences of soil erosion was landslides, with death $(11 \%)$ and soil infertility $(10 \%)$ as the next most frequent responses other than "Don't know", which comprised $28 \%$ of responses. Most (62\%) respondents obtained information about soil erosion from personal experience, followed by experiences related by family members $(16 \%)$. This suggests that community members usually react to soil erosion after it has occurred, rather than employing a cautionary approach of conservation practices learned from information provided by the government or schools. However, $42 \%$ of respondents indicated that the responsibility for solving soil erosion problems lies with government, while $26 \%$ indicated that responding to soil erosion is the responsibility of the community. More than $66 \%$ of respondents believed that reforestation is a viable option for reducing soil erosion. Several respondents added that, while reforestation is a useful soil conservation practice, they would only engage in reforestation if the government were to pay for it. Thirty-seven percent of respondents were currently employing reforestation practices on their land. Roughly a third of respondents indicated they were not following any conservation practices.

Several respondents said that reforestation activities have been limited by several issues. First, community members are required to complete a document requesting trees for reforestation; however, many community members are completely or partially illiterate in the languages on the forms; thus, they can not complete the forms. Second, the reforestation programs supply pines and cypress that can eventually be harvested for timber, but community members usually prefer oak trees because they are more accustomed to trees that provide firewood. Third, even when ignoring the problems of illiteracy and the preference for oak trees, the number of trees supplied to the communities each year for reforestation is usually insufficient to cover demand. While most respondents indicated that reforestation was important, many indicated that correction of soil erosion problems is interconnected with livelihood issues. For example, one respondent said "For us the forests are very important because we need them to obtain wood. We then use the wood for house construction or for furniture materials, or we sell it. That's why the forest is almost gone, because we use the good trees for wood so that we can earn money." Another respondent said that most people in the communities do not own large land areas and "If I reforest my land, where am I going to plant my maize? What am I going to eat? What will I give my kids to eat?" Several respondents mentioned that because they have big families, they can not dedicate more land for reforestation. However, some respondents indicated that they should conserve the land because it is the source of their livelihood.

\subsection{Combining variations in soil erosion rates and knowledge}

Differences in the KAP survey results between communities may offer information about their potential to engage in and sustain appropriate soil conservation practices. As a measure of this potential, the negative responses to the KAP survey questions were compiled by community, with the notion that lower negative response rates indicate a greater capacity to adopt soil conservation practices. The five negative responses included the following: "No" for knowledge of the term "soil erosion" and locations of most eroded areas; "Don't know" for the questions on causes of soil erosion, land use in eroded areas, consequences of soil erosion, and sources of information; "Don't know" or "No one" for the question on the re- 
Table 2. RUSLE factors and model results.

\begin{tabular}{lcr|rr|rr|rr}
\hline Community & $\begin{array}{c}\text { Soil erodibility } \\
\text { factor, } K\left(\mathrm{tha} \mathrm{ha}^{-1}\right. \\
\left.\mathrm{MJ}^{-1} \mathrm{~mm}^{-1}\right)\end{array}$ & $\begin{array}{c}\text { Length slope } \\
\text { factor, LS (-) }\end{array}$ & $\begin{array}{c}\text { Cover management } \\
\text { factor, } C(-)\end{array}$ & $\begin{array}{c}\text { Soil erosion rate, } \\
A\left(\mathrm{tha}^{-1} \mathrm{yr}^{-1}\right)\end{array}$ \\
\cline { 2 - 8 } & Mean & $\begin{array}{c}\text { Standard } \\
\text { deviation }\end{array}$ & Mean & $\begin{array}{r}\text { Standard } \\
\text { deviation }\end{array}$ & Mean & $\begin{array}{r}\text { Standard } \\
\text { deviation }\end{array}$ & $\begin{array}{r}\text { Mean } \\
\text { Standard } \\
\text { deviation }\end{array}$ \\
\hline Barrio La Union & 0.021 & 0.005 & 28 & 13 & 0.02 & 0.01 & 214 & 215 \\
Barrio Plan Grande & 0.028 & 0.006 & 14 & 8 & 0.02 & 0.01 & 156 & 87 \\
Barrio Vicente Guerrero & 0.022 & 0.005 & 36 & 17 & 0.03 & 0.00 & 340 & 184 \\
Benito Juárez Centro & 0.021 & 0.003 & 37 & 14 & 0.02 & 0.00 & 287 & 99 \\
Carrizal Centro & 0.018 & 0.005 & 29 & 16 & 0.03 & 0.00 & 234 & 161 \\
Poblado Cambil & 0.031 & 0.008 & 29 & 12 & 0.03 & 0.00 & 413 & 127 \\
All & 0.023 & 0.007 & 29 & 15 & 0.02 & 0.00 & 274 \\
\hline
\end{tabular}

sponsibility for solving soil erosion problems; "Don't know" or "Nothing" for the questions on practices for reducing soil erosion; and "No" for the question on whether there are solutions to the soil erosion problem.

Table 3 gives the percentages of negative responses normalized to the overall average percentage of negative responses by the community, $Y_{i, j}$, (where $i$ is the question index and $j$ is the community index) and, $\bar{Y}_{j}$, the percentage of negative responses averaged over all questions for each community, normalized by the overall average percentage for all communities. We estimated the Cronbach's alpha to assess the reliability of the overall measure of negative responses. The estimated $\alpha=0.84$ is substantially higher than the rule of thumb of $\alpha=0.7$ as a threshold for consistency; this indicates that the overall measure of negative responses reliably captures the response to the five questions selected to indicate the overall response. A multiple group $F$-test analysis on $\bar{Y}_{j}$ gives a $p$ value of 0.014 , implying that the values of $\bar{Y}_{j}$ are significantly different between each community.

Figure 2 shows the normalized percentage of negative responses averaged over all questions and the normalized average soil erosion rates (normalized to the overall average soil erosion rate) combining the results from Tables 2 and 3 . The figure demonstrates that Barrio Plan Grande is the least vulnerable community by these combined measures. However, separating the other communities in terms of vulnerability to soil erosion is not straightforward. Poblado Cambil has the highest normalized soil erosion rates and a relatively low normalized negative response rate. Barrio La Union has a relatively low normalized soil erosion rate and high normalized negative response rates. On the one hand, these results suggest that soil conservation efforts may have the greatest and lowest potential payoffs in communities with the characteristics of Poblado Cambil and Barrio La Union, respectively. On the other hand, the results suggest that Barrio Vicente Guerrero may be most vulnerable to soil erosion, since this community had the highest average negative response rate and the second highest soil erosion rate. At the very least,

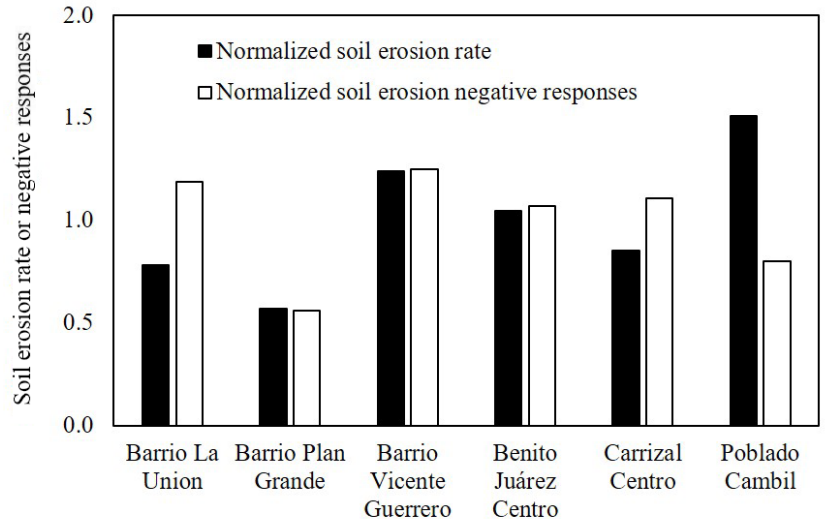

Figure 2. Combined results from Tables 2 and 3: normalized soil erosion rates and negative responses from the six study communities. Normalized soil erosion rates are calculated as the ratio of the average erosion rate for each community to the overall averages (see Table 2).

the results in Fig. 2 may be useful to natural resources managers in the communities and governmental agencies that are directing or participating in soil conservation and restoration efforts.

\section{Conclusions}

The purpose of this study was to assess variability in the vulnerability to soil erosion in six communities in the vicinity of Motozintla de Mendoza, Chiapas, Mexico. In this region soil erosion threatens the long-term viability of the local subsistence agriculture and creates hazards for downstream communities. The estimated average erosion rates in the communities range from 156 to $413 \mathrm{tha}^{-1} \mathrm{yr}^{-1}$, greatly exceeding rates indicated as very high by FAO $\left(>30 \mathrm{tha}^{-1} \mathrm{yr}^{-1}\right)$. Erosion rates are high due to steep and long slopes and high values of rainfall erosivity. Many of the highest soil erosion rates 


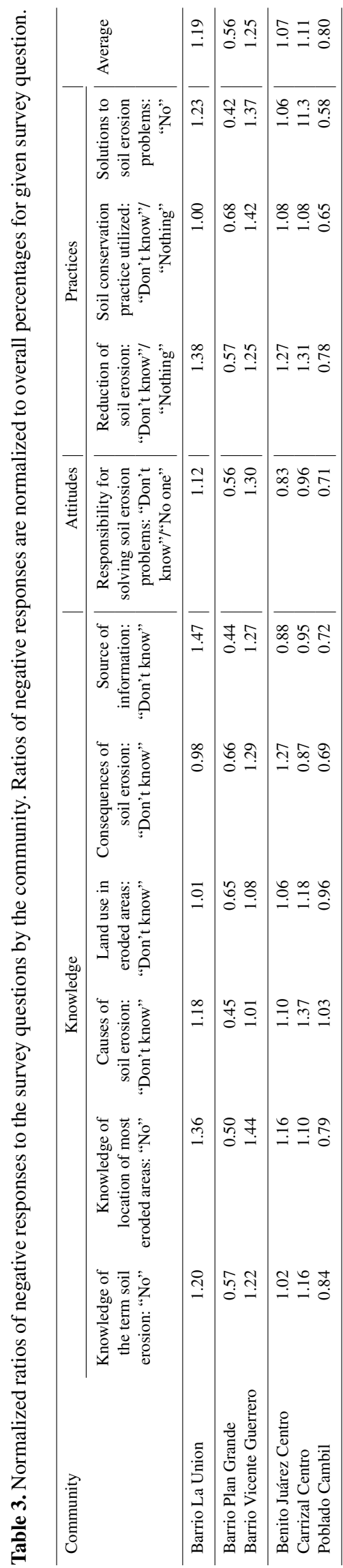

are found in communities that were dominated by forestland, but where most of the tree cover has now been removed. Conversely, the lower erosion rates are often found where corn is cultivated most of the year, providing more cover than forestland. Spatial variability in soil texture plays a smaller role in determining the spatial variability of soil erosion by community. According to the results of the soil erosion KAP survey, awareness of the concept of soil erosion was reasonably high in all of the communities, but awareness of the causes of erosion was considerably lower. More than half of respondents believed that reforestation is a viable option for reducing soil erosion, but only a third of respondents were currently implementing reforestation practices and another third indicated that they were not following any soil conservation practices. Survey respondents indicated that their adoption of government reforestation efforts have been hindered by the need to clear their land to sell forest products or for subsistence corn cultivation; additionally, respondents described difficulties in obtaining favorable tree stocks for reforestation.

The negative responses to key KAP survey questions were compiled into a single index and aggregated by community, which provides an indicator of the community's capacity to sustain erosion control measures. The index of negative responses varied substantially by community. When combined with the average soil erosion rates, we see that the relationship between the magnitude of the soil erosion problem and the capacity to reduce soil erosion is inconsistent across the communities. One community, Barrio Vicente Guerrero, had the highest average negative response rate and the second highest soil erosion rate, indicating that this community is particularly vulnerable. At the very least, these results may be useful to natural resources managers in the communities and governmental agencies that are directing or participating in soil conservation and restoration efforts. However, we conclude that as long as the economic and productive needs of the communities are not provided for in concert with the advance of soil conservation and restoration efforts, the risk of soil erosion will increase in the future, which threatens their prosperity and that of downstream communities.

Data availability. Plot-specific data on soil characteristics and community-specific results from the survey are available in the Supplement.

\section{The Supplement related to this article is available online} at https://doi.org/10.5194/se-9-745-2018-supplement.

Competing interests. The authors declare that they have no conflict of interest. 
Acknowledgements. This work was partially supported by the Higher Education for Development and US - Agency for International Development's US-Mexico Training, Internships, Exchanges, and Scholarships initiative. The authors gratefully acknowledge the support from the El Colegio de la Frontera Sur, San Cristóbal de las Casas, Chiapas, Mexico.

Edited by: Elias Samankassou

Reviewed by: two anonymous referees

\section{References}

Ajayi, O. C.: User acceptability of sustainable soil fertility technologies: Lessons from farmers' knowledge, attitude and practice in southern Africa, J. Sustain. Agr., 30, 21-40, 2007.

Altieri, M. A.: Agroecology: The science of sustainable agriculture, CRC Press, Boca Raton, Florida, USA, 2018.

Aparicio-Effen, M., Arana, I., Aparicio, J., Cortez, P., Coronel, G., Pastén, M., Nagy, G. J., Rojas, A. G., Flores, L., and Bidegain, M.: Introducing hydro-climatic extremes and Human Impacts in Bolivia, Paraguay and Uruguay, in: Climate Change and Health, Springer International Publishing, New York, USA, 449-473, 2016.

Arnoldus, H. M. J.: An approximation to the rainfall factor in the universal soil loss equation, in: Assessing Soil Degradation, FAO Soils Bulletin, Rome, Italy, issue 34, 127-132, 1980.

Assefa, E. and Bork, H. R.: Farmers' perception of land degradation and traditional knowledge in southern Ethiopia - Resilience and stability, Land Degrad. Dev., 27, 1552-1561, https://doi.org/10.1002/ldr.2364, 2015.

Babbar, B. K., Singla, N., and Singh, R.: Impact of village level education and training on adoption of control strategies, their sustainability and reduction in crop losses, Int. J. Adv. Res., 2, 672-683, 2014.

Baumann, J., Arellano Monterrosas, J. L., and Borgman, J.: Adaptation of the universal soil loss equation to the tropical Pacific coastal region of the Chiapas state, Mexico, in: 12th International Soil Conservation Organization (ISCO) Conference, 26-31 May 2002, Beijing, China, 518-523, 2002.

Baveye, P. C., Baveye, J., and Gowdy, J.: Soil “ecosystem” services and natural capital: Critical appraisal of research on uncertain ground, Frontiers in Environmental Science, 4, 41-53, 2016.

Biswas, H., Raizada, A., Mandal, D., Kumar, S., Srinivas, S., and Mishra, P. K.: Identification of areas vulnerable to soil erosion risk in India using GIS methods, Solid Earth, 6, 1247-1257, https://doi.org/10.5194/se-6-1247-2015, 2015.

Blackman, A., Pfaff, A., and Robalino, J.: Paper park performance: Mexico's natural protected areas in the 1990s, Global Environ. Chang., 31, 50-61, 2015.

Blaikie, P. and Brookfield, H. (Eds.): Land degradation and society, Routledge, New York, USA, 2015.

Brevik, E. C., Cerdà, A., Mataix-Solera, J., Pereg, L., Quinton, J. N., Six, J., and Van Oost, K.: The interdisciplinary nature of SOIL, SOIL, 1, 117-129, https://doi.org/10.5194/soil-1-1172015, 2015.

Brooks, K. N., Ffolliott, P. F., Gregersen, H. M., and DeBano, L. F.: Hydrology and the management of watersheds, Iowa State: Blackwell Professional, Ames, Iowa, USA, 2003.
Cayuela, L., Benayas, J. M. R., and Echeverría, C.: Clearance and fragmentation of tropical montane forests in the Highlands of Chiapas, Mexico (1975-2000), Forest Ecol. Manag., 226, 208218, 2006.

Chen, T., Niu, R., Li, P., Zhang, L., and Du, B.. Regional soil erosion risk mapping using RUSLE, GIS, and remote sensing: a case study in Miyun watershed, North China, Environmental and Earth Science, 63, 533-0541, 2011.

Comisión Federal de Electricidad (CFE): Programas de obras e inversiones del sector eléctrico 2014-2028, available at: http: //www.amdee.org/Publicaciones/POISE-2014-2028.pdf (last access: 17 July 2014), 2013.

Dabral, P. P., Baithuri, N., and Pandey, A.: Soil erosion assessment in a hilly catchment of North Eastern India using USLE, GIS and remote sensing. Water Resour. Manag., 22, 1783-1798, https://doi.org/10.1007/s11269-008-9253-9, 2008.

De Jong, B. H. J., Cairns, M. A., Haggerty, P. K., Ramirez-Marcial, N., Ochoa-Gaona, S., Mendoza-Vega, J., and March-Mifsut, I.: Land-use change and carbon flux between 1970s and 1990s in central highlands of Chiapas, Mexico, Environ. Manage., 23, 373-385, 1999.

Erkossa, T., Wudneh, A., Desalegn, B., and Taye, G.: Linking soil erosion to on-site financial cost: lessons from watersheds in the Blue Nile basin, Solid Earth, 6, 765-774, https://doi.org/10.5194/se-6-765-2015, 2015.

FAO: Status of the World's Soil Resources (SWSR) - Main Report. Food and Agriculture Organization of the United Nations and Intergovernmental Technical Panel on Soils, Rome, Italy, 2015.

Fernández, C. and Vega, J. A.: Evaluation of RUSLE and PESERA models for predicting soil erosion losses in the first year after wildfire in NW Spain, Geoderma, 273, 64-72, 2016.

Fernandez, C., Wu, J., McCool, D., and Stöckle, C.: Estimating water erosion and sediment yield with GIS, RUSLE, and SEDD, J. Soil Water Conserv., 58, 128-136, 2003.

Foster, G. R.: Science Documentation, Revised Universal Soil Loss Equation Version 2, in: National Sedimentation Laboratory UARS, Oxford, Mississippi, USA, 2005.

Foster, G. R., Meyer, L. D., and Onstad, C. A.: An erosion equation derived from basic erosion principles, Transactions of the American Society of Agricultural Engineers, 20, 678-682, 1977.

García-Barrios, L., Galván-Miyoshi, Y. M., Valdivieso-Pérez, I. A., Masera, O. R., Bocco, G., and Vandermeer, J.: Neotropical forest conservation, agricultural intensification, and rural outmigration: The Mexican experience, Bioscience, 59, 863-873, 2009.

Gomiero, T.: Soil degradation, land scarcity and food security: Reviewing a complex challenge., Sustainability, 8, 281-287, 2016.

González-Espinosa, M. and Brunel-Manse, C. (Eds.): Montañas, pueblos y agua. Dimensiones y realidades de la cuenca Grijalva, vol. I. Ediciones Juan Pablos, Mexico City, Mexico, 2014.

González-Espinosa, M., Ramírez-Marcial, N., Gómez-Pineda, E., Parra-Vázquez, M. R., Díaz-Hernández, B. M., and MusálemCastillejos, K.: Vulnerabilidad ambiental y social. Perspectivas de restauración de bosques en las partes altas de la Sierra Madre de Chiapas, Investigación Ambiental Ciencia y Política Pública, 6, 89-108, 2015.

Gordillo, G. C. Á.: Las percepciones del riesgo. El caso del huracán Stan en Motozintla, Chiapas. Sociedad y desigualdad en Chiapas: 
24. El Colegio de la Frontera Sur, San Cristóbal de Las Casas, Chiapas, Mexico, 2009.

Gumucio, S.: Data Collection (Quantitative Methods). The KAP Survey Model, IGC Communigraphie, Saint Etienne, France, 2011.

Gutierrez-Horacio, R. and Triana-Ramirez, C.: Gestión integrada de crecientes caso de studio México: Rio Grijalva. Associated Programme on Flood Management, available at: http://www. apfm.info/publications/casestudies/cs_mexico_full.pdf, (last access: 22 May 2016), 2006.

Hooke, R. L.: On the history of humans as geomorphic agents, Geology, 28, 843-846, https://doi.org/10.1130/00917613(2000)28<843:OTHOHA >2.0.CO;2, 2000.

Instituto Nacional de Estadística, Geografía e Informática (INEGI): Uso de suelo y vegetación, Chiapas state 1:250000, available at: http://www.inegi.org.mx/geo/contenidos/recnat/usosuelo/, last access: 22 February 2015.

IUSS Working Group World Reference Base: International soil classification system for naming soils and creating legends for soil maps, World Soil Resources Reports, No. 106, FAO, Rome, Italy, 2015.

Jain, S. K., Kumar, S., and Varghese, J.: Estimation of Soil Erosion for a Himalayan Watershed Using GIS Technique, Water Resour. Manag., 15, 41-54, 2001.

Jara-Rojas, R., Bravo-Ureta, B. E., Engler, A., and Díaz, J.: An analysis of the joint adoption of water conservation and soil conservation in Central Chile, Land Use Policy, 32, 292-301, https://doi.org/10.1016/j.landusepol.2012.11.001, 2013.

Jasrotia, A. S. and Singh, R.: Modeling runoff and soil erosion in a catchment area, using the GIS, in the Himalayan region, India, Environ. Geol., 51, 29-37, https://doi.org/10.1007/s00254-0060301-6, 2006.

Keesstra, S. D., Pereira, P., Novara, A., Brevik, E. C., AzorinMolina, C., Parras-Alcántara, L., Jordán, A., and Cerdà, A.: Effects of soil management techniques on soil water erosion in apricot orchards, Sci. Total Environ., 551, 357-366, 2016 a.

Keesstra, S. D., Bouma, J., Wallinga, J., Tittonell, P., Smith, P., Cerdà, A., Montanarella, L., Quinton, J. N., Pachepsky, Y., van der Putten, W. H., Bardgett, R. D., Moolenaar, S., Mol, G., Jansen, B., and Fresco, L. O.: The significance of soils and soil science towards realization of the United Nations Sustainable Development Goals, SOIL, 2, 111-128, https://doi.org/10.5194/soil-2-111-2016, 2016 b.

Kelly, B., Allan, C., and Wilson, B. P.: Soil indicators and their use by farmers in the Billabong Catchment, southern New South Wales, Aust. J. Soil Res., 47, 234-242, https://doi.org/10.1071/SR08033, 2009.

Knowler, D. and Bradshaw, B.: Farmers' adoption of conservation agriculture: A review and synthesis of recent research, Food Policy, 32, 25-48, 2007.

Kouli, M., Soupios, P., and Vallianatos, F.: Soil erosion prediction using the Revised Universal Soil Loss Equation (RUSLE) in a GIS framework, Chania, Northwestern Crete, Greece, Environ. Geol., 57, 483-497, https://doi.org/10.1007/s00254-008-1318-9, 2009.

Laino-Guanes, R. E., González-Espinosa, M., Ramírez-Marcial, N., Bello-Mendoza, R., Jiménez, F., Casanoves, F., and MusálemCastillejos, K.: Human pressure on water quality and water yield in the upper Grijalva river basin in the Mexico-
Guatemala border, Ecohydrology \& Hydrobiology, 16, 149-159, https://doi.org/10.1016/j.ecohyd.2015.12.002, 2016.

Lal, R.: Soil erosion and the global carbon budget, Environ. Int., 29, 437-450, https://doi.org/10.1016/S0160-4120(02)00192-7, 2003.

Launiala, A.: How much can a KAP survey tell us about people's knowledge, attitudes and practices? Some observations from medical anthropology research on malaria in pregnancy in Malawi, Anthropology Matters, 11, 1-8, 2009.

Leh, M., Bajwa, S., and Chaubey, I.: Impact of land use change on erosion risk: and integrated remote sensing geographic information system and modeling methodology, Land Degrad. Dev., 24, 409-421, https://doi.org/10.1002/ldr.1137, 2013.

Lu, D., Li, G., Valladares, G. S., and Batistella, M.: Mapping soil erosion risk in Rondônia, Brazilian Amazonia: Using RUSLE, remote sensing and GIS, Land Degrad. Dev., 15, 499-512, 2004.

Marques, M. J., Bienes, R., Cuadrado, J., Ruiz-Colmenero, M., Barbero-Sierra, C., and Velasco, A.: Analysing perceptions attitudes and responses of winegrowers about sustainable land management in central Spain, Land Degrad. Dev., 26, 458-467, 2015.

McCool, D. K., Foster, G. R., Mutchler, C. K., and Meyer, L. D.: Revised slope length factor for the Universal Soil Loss Equation, T. ASAE, 32, 1571-1576, 1989.

McCool, D. K., Foster, G., and Weesies, G.: Slope-length and steepness factors (LS). Predicting Soil Erosion by Water: A Guide to Conservation Planning with the Revised Universal Soil Loss Equation (RUSLE), USDA Agriculture Handbook no. 703, Washington, D.C., USA, 1997.

Millward, A. A. and Mersey, J. E.: Adapting the RUSLE to model soil erosion potential in a mountainous tropical watershed, Catena, 38, 109-129. https://doi.org/10.1016/S03418162(99)00067-3, 1999.

Naipal, V., Reick, C., Pongratz, J., and Van Oost, K.: Improving the global applicability of the RUSLE model - adjustment of the topographical and rainfall erosivity factors, Geosci. Model Dev., 8, 2893-2913, https://doi.org/10.5194/gmd-8-2893-2015, 2015.

Ochoa-Gaona, S.: Traditional land-use systems and patterns of forest fragmentation in the highlands of Chiapas, Mexico, Environ. Manage., 27, 571-586, 2001.

Ochoa-Gaona, S. and González-Espinosa, M.: Land use and deforestation in the highlands of Chiapas, Mexico, Appl. Geogr., 20, 17-42, 2000.

Ostovari, Y., Ghorbani-Dashtakia, S., Bahramib, H.-A., Naderia, M., and Demattec, J. A. M.: Soil loss prediction by an integrated system using RUSLE, GIS and remote sensing in semiarid region, Geoderma Regional, 11, 28-36, 2017.

Panagos, P., Borrelli, P., Meusburger, K., Alewell, C., Lugato, E., and Montanarella, L.: Estimating the soil erosion covermanagement factor at the European scale, Land Use Policy, 48, 38-50, 2015.

Pandey, A., Mathur, A., Mishra, S. K., and Mal, B. C.: Soil erosion modeling of a Himalayan watershed using RS and GIS, Environ. Earth Sci., 59, 399-410, https://doi.org/10.1007/s12665009-0038-0, 2009.

Pereira, P., Mierauskas, P., and Novara, A.: Stakeholders' perceptions about fire impacts on Lithuanian protected areas, Land Degrad. Dev., 27, 871-883, 2016.

Pielke, R. A., Adegoke, J., Chase, T. N., Marshall, C. H., Matsui, T., and Niyogi, D.: A new paradigm for assessing the role of agri- 
culture in the climate system and in climate change, Agr. Forest Meteorol., 142, 234-254, 2007.

Pimentel, D. and Burgess, M.: Soil erosion threatens food production, Agriculture, 3, 443-463, 2013.

Pimentel, D., Harvey, C., Resosudarmo, P., Sinclair, K., Kurz, D., McNair, M., and Blair, R.: Environmental and economic costs of soil erosion and conservation benefits, Science, 267, 1117-1123, https://doi.org/10.1126/science.267.5201.1117, 1995.

Prasannakumar, R., Shiny, N., Geetha, H., and Vijith, H.: Spatial prediction of soil erosion risk by remote sensing, GIS and RUSLE approach: A case study of Siruvani river watershed in Attapady valley, Kerala, India, Environ. Earth Sci., 64, 965-972, 2011.

Prasannakumar, V., Vijith, H., Abinod, S., and Geetha, N.: Estimation of soil erosion risk within a small mountainous subwatershed in Kerala, India, using Revised Universal Soil Loss Equation (RUSLE) and geo-information technology, Geosci. Front., 3, 209-215, https://doi.org/10.1016/j.gsf.2011.11.003, 2012.

Ramírez-Marcial, N., González-Espinosa, M., and WilliamsLinera, G.: Anthropogenic disturbance and tree diversity in montane rain forests in Chiapas, Mexico, Forest Ecol. Manag., 154, 311-326, 2001.

Ramírez-Marcial, N., González-Espinosa, M., MusálemCastillejos, K., Noguera-Savelli, E., and Gómez-Pineda, E.: Estrategias para una construcción social de la restauración forestal en comunidades de la cuenca media y alta del río Grijalva, in: Montañas, pueblos y agua. Dimensiones y realidades de la cuenca Grijalva, edited by: González-Espinosa, M. and Brunel-Manse, C., Ediciones Juan Pablos, Mécico City, Mexico, 518-554, 2014.

Renard, K. G., Foster, G., Weesies, G., McCool, D., and Yoder, D.: Predicting soil erosion by water: a guide to conservation planning with the Revised Universal Soil Loss Equation (RUSLE), Agricultural Handbook No. 703, US Department of Agriculture, Washington, D.C., USA, 65-100, 1997.

Renard, K. G. and Freimund, J. R.: Using monthly precipitation data to estimate the R-factor in the revised USLE, J. Hydrol., 157, 287-306, https://doi.org/10.1016/0022-1694(94)90110-4, 1994.

Sánchez-Núñez, J. M., Macías, J. L., Zamorano-Orozco, J. J., Saucedo, R., Torres, J. R., and Novelo, D.: Mass movement processes at the Motozintla Basin, Chiapas, Southern Mexico, Geofis. Int., 51, 169-184, https://doi.org/10.1007/s00531-0060093-7, 2012.

Sanchez-Nuñez, J. M., Macías, J. L., Saucedo, R., Zamorano, J. J., Novelo, D., Mendoza, M. E., and Torres-Hernández, J. R.: Geomorphology, internal structure and evolution of alluvial fans at Motozintla, Chiapas, Mexico, Geomorphology, 230, 1-12, 2015.

Santacruz-DeLeon, G.: Estimate of water erosion and its relationship to land use in the cahoacan river basin, Chiapas, Mexico, International Hydrological Programme (IHP) of the United Nations Educational, Scientific and Cultural Organization (UNESCO), Paris, France, 3, 45-62, 2011.

Santibañez, Q. and Santibáñez, P.: Trends in Land Degradation in Latin America and the Caribbean, the role of climate change EN: Climate and Land Degradation World Meteorological Organization, Ginebra, Springer Verlag, Berlin, Germany, 65-81, 2007.

Secretaria de Medio Ambiente y Recursos Naturales (SEMARNAT): NOM-021-RECNAT-2000. Parte 2: Especificaciones de fertilidad, salinidad y clasificaciones de suelos. Estudios, muestreo y analisis. Mexico, Diario Oficial de la Federacion (D.O.F), Mexico DF, 2002.

Secretaria de Medio Ambiente y Recursos Naturales (SEMARNAT): Degradación de suelos en México. Informe de la situación del medio ambiente en México. Compendio de estadísticas ambientales, available at: http://apps1.semarnat.gob.mx/dgeia/ informe_2008_ing/03_suelos/cap3_2.html (last access: 17 July 2014), 2008.

Sibiya, J. E. and Gumbo, J. R.: Knowledge, attitude and practices (KAP) survey on water, sanitation and hygiene in selected schools in Vhembe District, Limpopo, South Africa, Int. J. Env. Res. Pub. He., 10, 2282-2295, 2013.

Smith, P., Cotrufo, M. F., Rumpel, C., Paustian, K., Kuikman, P. J., Elliott, J. A., McDowell, R., Griffiths, R. I., Asakawa, S., Bustamante, M., House, J. I., Sobocká, J., Harper, R., Pan, G., West, P. C., Gerber, J. S., Clark, J. M., Adhya, T., Scholes, R. J., and Scholes, M. C.: Biogeochemical cycles and biodiversity as key drivers of ecosystem services provided by soils, SOIL, 1, 665685, https://doi.org/10.5194/soil-1-665-2015, 2015.

Stallard, R F.: Terrestrial sedimentation and the carbon cycle: Coupling weathering and erosion to carbon burial, Global Biogeochem. Cy., 12, 231-257, https://doi.org/10.1029/98GB00741, 1998.

Suarez-Diaz, J.: Analisis de los problemas de erosión de deslaves; Carretera Huixtla-Motozintla, Chiapas. Instituto de erosion y deslizamientos, Bucaramanga, Colombia, 2006.

Subirós, J. V., Rodríguez-Carreras, R., Varga, D., Ribas, A., Úbeda, X., Asperó, F., Llausàs, A., and Outeiro, L.: Stakeholder Perceptions of Landscape Changes in the Mediterranean Mountains of the North-Eastern Iberian Peninsula, Land Degrad. Dev., 27, 1354-1365, 2016.

Tesfahunegn, G. B.: Soil quality indicators response to land use and soil management systems in northern Ethiopia's catchment, Land Degrad. Dev., 27, 438-448, https://doi.org/10.1002/ldr.2245, 2013.

Teshome, A., De Graaff, J., Ritsema, C., and Kassie, M.: Farmers' perceptions about the influence of land quality, land fragmentation and tenure systems on sustainable land management in the north western ethiopian highlands, Land Degrad. Dev., 27, 884 898, https://doi.org/10.1002/ldr.2298, 2014.

Toledo-Aceves, T., Meave, J. A., González-Espinoza, M., and Ramírez-Marcial, N.: Tropical montane cloud forests: current threats and opportunities for their conservation and sustainable management in Mexico, J. Environ. Manage., 92, 974-981, https://doi.org/10.1016/j.jenvman.2010.11.007, 2011.

Tuyet-Hanh, T. T., Anh, V. L., Dunne, M. P., Tenkate, T., Toms, L. M., and Harden, F.: The effectiveness of an intervention in reducing risk of dioxin exposure in Da Nang: changes in community knowledge, attitudes and prevention practices after 2.5 years, Vietnam Journal of Public Health, 1, 12-21, 2013.

UNCCD: A Stronger UNCCD for a Land-Degradation Neutral World, Issue Brief, UNCCD secretariat, Bonn, Germany, 2013.

WHO: Advocacy, communication and social mobilization for TB control: a guide to developing knowledge, attitude and practice surveys, available at: http://whqlibdoc.who.int/publications/ 2008/9789241596176_eng.pdf (last access: 12 July 2015), 2008. 
Wilkinson, B. H. and McElroy, B. J.: The impact of humans on continental erosion and sedimentation, Bull. Geol. Soc. Am., 119, 140-156, https://doi.org/10.1130/B25899.1, 2007.

Wilson, G. A., Kelly, C. L., Briassoulis, H., Ferrara, A., Quaranta, G., Salvia, R., Detsis, V., Curfs, M., Cerda, A., El-Aich, A., and Liu, H.: Social memory and the resilience of communities affected by land degradation, Land Degrad. Dev., 28, 383-400, https://doi.org/10.1002/ldr.2669, 2016.

Wischmeier, W. H., Johnson, C. B., and Cross, B. V.: Soil erodibility nomograph for farmland and construction sites, J. Soil Water Conserv., 23, 189-193, 1971.

Yin, S., Xie, Y., Liu, B., and Nearing, M. A.: Rainfall erosivity estimation based on rainfall data collected over a range of temporal resolutions, Hydrol. Earth Syst. Sci., 19, 4113-4126, https://doi.org/10.5194/hess-19-4113-2015, 2015.
Yoder, D. C., Porter, J. P., Laflen, J. M., Simantonn, J. R., Renard, K. G., and McCool, D. K.: Cover-management factor (C), in: Agricultural Handbook No. 703, US Department of Agriculture, Washington, D.C., USA, p. 404, 1997.

Yue-Qing, X., Jian, P., and Xiao-Mei, S.: Assessment of soil erosion using RUSLE and GIS: a case study of the Maotiao River watershed, Guizhou Province, China, Environ. Geol., 56, 1643-1652, 2008.

Zegeye, A. D., Steenhuis, T. S., Blake, R. W., Kidnau, S., Collick, A. S., and Dadgari, F.: Assessment of soil erosion processes and farmer perception of land conservation in Debre Mewi watershed near Lake Tana, Ethiopia, Ecohydrology and Hydrobiology, 10, 297-306, 2010.

Zhang, K. L., Shu, A. P., Xu, X. L., Yang, Q. K., and Yu, B.: Soil erodibility and its estimation for agricultural soils in China, J. Arid Environ., 72, 1002-1011, 2008. 